\title{
THE PRACTICE OF CITY RESIDENTS IN INFORMALITY RIVERBANKS WINONGO YOGYAKARTA CITY
}

\author{
Rosesynta Paramita, Akhmad Ramdhon
}

Universitas Sebelas Maret

rosesynta@gmail.com

Article History

accepted 09/07/2018

approved 01/08/2018

published 17/09/2018

\section{Keywords}

city-village, informality, winongo River

\begin{abstract}
The city is a network of human life which is characterized by a high population density with colorful heterogeneous socioeconomic strata and materialist. Cities in Indonesia is currently undergoing a fairly rapid growth rate. This makes more and more people are interested to move and settle in the city. The impact of the activity of the townspeople always affects the environment inside. The river is one of the influences of the ecological activity of the city. The banks of the river became the site of the settlement of the community we callcity-village. City-Village inhabited by natives or newcomers with limited conditions that do daily activities to maintain his presence in the city. This research aims to 1) Describes social conditions the city-village of Winongo riverbanks. 2) The physical condition of the environment Winongo riverbanks. 3) Describes the everyday practice of residents of the city on the Winongo River. In this study used the thought of Pierre Bourdieu's theory of capital. This study uses qualitative methods, Descriptive approach to generate the information. The selected informer is the original city residents, expat residents and FKWA as the Winongo River Community. Data collection using in-depth interviews, observation, and documentation. The research results showed that: 1) CityVillage of winongo riverbanks have dynamics over time. Changes in total population seriring just time to make settlements in the city is getting memeadat. The presence of many routine activities collectively used to tie the laces of cityvillage on the Winongo River. 2) The physical condition of the city-villages and river more start specially degraded river conditions began declining quality is due to receive waste from human activities. Waste into the Winongo probelm and there needs to be an awareness to preserve the Winongo. 3) Everyday lives practice showed that the city-village's Winongo riverbanks most of all its citizens with low socio economic circles. The daily activities of the city-village of this town is a form of adaptation should be done to connect to live. The idea of Bourdieu about capital, proved to be the fifth capital used in the everyday life of the city-village in sustaining life. Reciprocal relationships, networks, norms and trust strengthen city residents living in activity and connect live.
\end{abstract}

Social, Humanities, and Education Studies (SHEs): Conference Series https://jurnal.uns.ac.id/shes
p-ISSN 2620-9284

e-ISSN 2620-9292 


\section{PENDAHULUAN}

Kota menurut Bintarto merupakan sistem jaringan kehidupan manusia yang ditandai dengan kepadatan penduduk yang tinggi dengan warna-warni strata sosial ekonomi yang heterogen dan materialis (Adon Nasrullah, 2015:42). Kota menjadi benteng budaya yang muncul karena disengaja dan tidak disengaja dengan pemusatan penduduk yang besar sekaligus bersifat heterogen. Dengan sifat khasnya yang heterogen, kota hadir dengan banyak keragaman kelompok sosial didalamnya yang bisa kita telusur melalui pelaspisan, mobilitas, pekerjaan, pendidikan, interaksi, norma dan nilai. Kota memberi beragam tanda pengenal untuk kita, seperti kota tempat perdagangan dimana pasar selalu menjadi titik penting dari sebuah kota, selain itu kota memberi tanda mengenai jalur distribusi barang dan pemberhentian manusia lain. Maraknya pembangunan-pembangunan yang terjadi di kota secara langsung dapat memacu pertumbuhan ekonomi kota itu sendiri.

Banyak kota berkembang dalam berbagai aspek, baik fisik-ekonomi-sosial sebagai hasil kemajuan pengetahuan dan teknologi. Sebagai konsekuensi dari pembangunan yang super cepat tersebut maka kota menjadi magnet bagi penduduk untuk berdatangan mencari pekerjaan dan bertempat tinggal. Kota meracuni para penduduk desa untuk berpindah ke kota. Perpindahan penduduk ke kota tersebut menimbulkan beragam problem, sebab tidak ada pengendalian didalamnya. Over urbanisasi terjadi terutama pada negara-negara dengan ketimpangan pertumbuhan antar wilayah. Semakin banyak masalah yang timbul sebagai dampak pembangunan kota, lalu masalah tersebut membuat para perencana dan pengatur kota harus meluaskan lagi wilayahnya tidak hanya meluas tapi juga menegak, gedung-gedung pencakar langit mulai berdiri.

Dengan tidak meratanya pembangunan permukiman kota memicu merebaknya permukiman kumuh yang dapat meciptakan kemerosotan lingkungan yang diikuti kemerosotan kualitas hidup masyarakatnya. Pemandangan Kota akan permukiman kumuh, kejahatan kota (urban crime), kesulitan terhadap akses sumberdaya menjadi hal yang lumrah atau wajar. Kemajuan yang berhasil diperoleh kota-kota di Indonesia masa kini tetap saja memunculkan dampak-dampak kerugian bagi kota. Kota dengan tindak kriminalitasnya yang menjadi penghilang kententraman dan ketertiban masyarakat kota namun dilain sisi menjadi jalan keluar dari pemenuhan kebutuhan. Marginalitas ekonomi, sosial dan budaya masih saja dirasakan oleh sebagian penduduk perkotaan. Kaum pinggiran perkotaan menjadi bentuk nyata keberadaan kaum yang kurang beruntung cerminan dari hidup yang serba terbatas.

Masyarakat yang tidak memiliki pilihan lain di perkotaan biasanya tinggal menggerombol dalam suatu kawasan yang disebut kampung. Kampung di perkotaan sering dinomor sekiankan dan kurang perhatian dari beberapa akademisi dan birokrat negara. Kampung dianggap menjadi hal yang kurang penting karna keterbatasan warganya. Kampung sering mendapat labelling kumuh, kotor, sempit, tidak teratur dan ilegal oleh para pemangku kebijakan kota yang itu semua hanya bisa diperbaiki melalui fisik. Lebih jauh kampung sendiri bisa kita pahami sebagai ruang yang memiliki jaringan relasi sosial diantara warganya. Jaringan sosial inilah yang membentuk kampung-kampung diperkotaan. Justru akan menimbulkan hal yang lebih runyam ketika para pemerintah memberi kebijakan dengan mengesampingkan aspek sosial.

Kampung menjadi rawan akan penggusuran dan penghancuran. Ketika kampung-kampung dibongkar dan beralih menjadi ruang untuk kepentingan pribadi seperti gedung-gedung modern, mal, hotel, kantor, ruko dan pelebaran jalan. Kampung menjadi proyek modernisasi yang jauh lebih besar ( J.A Khusyairi 2002:397). Kampung memiliki peranan yang positif bagi kota, karena ia menyediakan tempat untuk warganya memperoleh akses pendapatan dengan segala keterbatasan yang ada untuk tetap mempertahankan hidup. 
Informalitas tidak hanya menjadi suatu kenyataan pahit yang dirasakan oleh orang kampung di perkotaan namun menjadi suatu cara untuk bertahan hidup dan membangun sistem sosial, budaya dan ekonomi mereka sendiri. Pesatnya perkembangan kota sebagai praktik dari modernisasi saat ini tidak disertai dengan pertambahan kesempatan kerja dan kesempatan hidup layak yang merata. Kaum urban yang tidak memiliki kesempatan untuk menikmati modernisasi di kota harus berjuang keluar dari kemiskinan, permukiman kumuh, sulitnya mendapatkan akses kesehatan maupun akses pendidikan, ilegalitas dan ketertinggalan. Mengalami semua kondisi tersebut mereka bertahan dengan cara mereka sendiri, bertaruh menjadi tenaga kerja di sektor ekonomi kota atau membangun ekonomi mereka sendiri di kampung mereka tinggal.

Dengan segala kekuatan dan kekurangan masyarakat urban ini mencoba berkerja dimana cara tersebut mampu menghadirkan peluang kerja untuk angkatan kerja ketika pemerintah atau program pembangunan kurang mampu melakukan itu. Masalah mendasar yang bersifat struktural dirumuskan seperti buruknya perbandingan luas tanah dan jumlah penduduk lalu buruknya pola pemilikan tanah. Pentingnya partisipasi kaum kecil pada pemutusan kebijakan pembangunan, mereka diberi dorongan untuk mengorganisir diri sendiri sehingga hak dan kepentingan mereka terjamin.

Masyarakat kecil kota merupakan sumberdaya politik yang kehilangan daya politiknya bagi kepentingan mereka sendiri (Rachbini, 1994). Salah satu realita informalitas yang akan diangkat dalam riset ini, masyarakat urban menempati sepadan sungai di kawasan pusat kegiatan kota yakni daerah bantaran sungai Winongo di Kota Yogyakarta dengan segala praktik keseharian mereka. Kaum migran yang datang di bantaran sungai Winongo berasal dari wilayah sekitar Wonosari, Kulon Progo, Wonogiri, Solo, Madura akhirnya menempati lahan wedhi kengser Kota Yogyakarta. Sungai winongo merupakan salah satu sungai yang melintasi permukiman padat penduduk di Daerah Istimewa Yogyakarta.

Kondisi masyarakat bantaran yang serba terbatas, kekurangan akses, dan menengah kebawah menjadi praktik informalitas atau keseharian yang terjadi di kota. Praktik keseharian warga kampung merupakan realitas strategi beradaptasi masyarakat bantaran sungai terhadap kondisi sosial dan fisik lingkungan di kawasan bantaran Kali Winongo Kota Yogyakarta.

\section{METODE}

Lokasi penelitian dilakukan di Kampung Kota bantaran sungai winongo kota Yogyakarta. Alasan memilih lokasi penelitian ini karena di bantaran sungai winongo kota Yogyakarta merupakan salah satu kampung marjinal yang memungkinkan peneliti menangkap praktik keseharian sebagai strategi adaptasi untuk bertahan hidup. Penelitian dilaksanakan pada 1 desember 2017 sampai 1 Mei 2018. Tahapan Penelitian:

1. Persiapan Penelitian

- Membuat surat ijin penelitian

- Penyusunan instrumen penelitian (interview guide)

2. Pelaksanaan Penelitian

- Penelitian ini adalah penelitian kualitatif dengan menggunakan pendekatan Deskriptif. Teknik pengumpulan data menggunakan teknik wawancara mendalam, observasi, serta di lengkapi dengan dokumentasi.

- Untuk menguji data menggunakan triangulasi sumber. Sedangkan teknik analisis data menggunakan teknik analisis interaktif yang dimulai dengan pengumpulan data, reduksi data, penyajian data, penarikan kesimpulan. 


\section{HASIL DAN PEMBAHASAN}

\section{Kondisi Sosial dan fisik Sungai Winongo Profil ekologi sungai winongo}

Kota Yogyakarta sendiri terdapat 3 sungai besar yang mengalir dari arah Utara ke Selatan yaitu Sungai Gajah Wong yang mengalir di bagian Timur kota, Sungai Code di bagian tengah dan Sungai Winongo di bagian Barat kota (Kota Yogyakarta dalam Angka, 2017). Sungai merupakan bagian penting dalam kehidupan manusia untuk kelangsungan hidup. Sungai dimanfaatkan oleh manusia sebagai sumber air, sumber pangan, dan sarana transportasi. Menurut Peraturan Pemerintah No. 35 Tahun 1991, sungai adalah tempat-tempat atau wadah-wadah serta jaringan pengaliran air mulai dari mata air sampai muara dengan dibatasi kanan kirinya serta sepanjang pengalirannya oleh garis sepadan. Dari sungai-sungai yang terdapat di Kota Yogyakarta tersebut yang menjadi fokus penelitian penulis adalah Sungai Winongo yang melintas di daerah perkotaan Yogyakarta.

Sungai Winongo merupakan salah satu sungai yang melintas Daerah Istimewa Yogyakarta, yang berhulu di Sleman dan bermuara di Bantul. Sungai Winongo berada di bagian barat Kota Yogyakarta dengan panjang total sungai sekitar $48 \mathrm{~km}$, sedangkan panjang bagian tengah alur sungai yang melintas di Kota Yogyakarta adalah 7,06 km (SLHD Kota Yogyakarta, 2014: 13). Di daerah perkotaan, awal sungai winongo adalah wilayah Bener/Kricak dan berakhir di Patangpuluhan. Kondisi bantaran sungai winongo di beberapa wilayah masih menunjukan sifat kealamiannya dengan berbagai vegetasi dan lahan kosong. Kondisi mata air di kawasan hulu dan hilir masih asli dan belum banyak dimanfaatkan. Di kawasan perkotaan, sempadan sudah dipadati kawasan permukiman. Kondisi mata air tertutup oleh talud pasangan batu yang akhinya mematikan sumber air. Walaupun di beberapa titik mata air masih mengalir dan dimanfaatkan warga. Perkembangan wilayah Kota Yogyakarta dan sekitarnya khususnya daerah bantaran sungai menyebabkan tekanan terhadap Sungai Winongo semakin meningkat.

Kampung Bangunrejo merupakan salah satu kampung-kota yang paling dinamis dan representatif dengan tema penulis, yang berada di segmen Becak Maju Sungai Winongo. Kampung Bangunrejo RW 13 merupakan kampung yang terletak di Kelurahan Kricak Kecamatan Tegalrejo, selain itu kampung ini di bantaran sungai winongo yang memiliki ikon sebagai kampung wisata budaya. Terpampang di gapura kampung dengan tulisan Kampung Wisata Budaya Bangunrejo. Kelurahan Kricak memiliki batas wilayah secara administratif yakni sisi utara berbatasan dengan Kabupaten sleman, sisi selatan berbatasan dengan kelurahan Bumijo, sisi Timur berbatasan dengan kelurahan karangwaru, dan sisi Barat berbatasan dengan kelurahan Bener. Menurut data Laporan TKPK Kota Yogyakarta tahun 2016, Kelurahan Kricak memiliki luas wilayah $0,82 \mathrm{~km}^{2}$ dengan jumlah RW sebanyak tigabelas dan jumlah RT sebanyak enampuluhsatu didalamnya.

Secara Historis yang berkembang di kalangan warga kampung asal-usul kampung Bangunrejo sendiri adalah sesepuh bernama Kyai Bangu yang dikubur pertama di wilayah ini, lama-kelamaan berangsur menjadi Bangunrejo. Kondisi permukiman di Kampung Bangunrejo sendiri mayoritas mepet dengan sungai, tidak ada jeda antara sungai dan rumah, akan tetapi jika semakin ke atas, beberapa rumah mulai memberi jalan di belakang rumahnya yang langsung di tepian sungai, jalan ini bisa dilewati pejalan kaki, ataupun motor, mayoritas rumah menghadap ke jalan, tidak ke sungai. Lalu di tepian sungai juga dimanfaatkan sebagai taman bermain anak dan ruang berkumpul.

Akses terhadap fasilitas publik yang pertama adalah kesehatan, ditemukannya Posyandu balita dan lansia. Lalu untuk fasilitas pendidikan Kampung Bangunrejo warga biasanya menyekolahkan anak-anak mereka ke SDN Bangunrejo I dan II yang 
berstandarkan SSB (Sekolah Siaga Bencana). Pelatihan Tanggap Bencana kepada anak-anak sangat diperlukan karena semakin banyak pengetahuuan yang mereka miliki akan memudahkan mereka sebagai kelompok rentan apabila terjadi bencana. Sementara itu untuk fasilitas lainnya seperti gedung Lembaga Pengembangan Masyarakat Kelurahan (LPMK) Kricak terdapat juga di kampung Bangunrejo. Ditemukan juga papan di sebuah rumah warga bertuliskan Kecamatan Inklusi Ramah Difabel. Warga Kampung Bener tidak jauh dari akses-akses layanan publik kota karena lokasi Kampung yang sangat strategis. Kampung ini sendiri dapat dijangkau oleh transportasi umum namun hanya pada depan kampung di Jalan Raya Jogja Magelang. Secara kewilayahan Kampung Bangunrejo sendiri merupakan kampung yang awalnya memiliki tiga RW , namun pada Tahun 1991 terjadi pemekaran karena pertumbuhan jumlah penduduk informasi juga disampaikan oleh Bapak Sarko selaku Ketua RW 13 di Kampung Bangunrejo.

Meningkatnya jumlah penduduk kampung Bangunrejo membuat Pemerintah memutuskan kebijakan perluasan wilayah Kampung Bangunrejo. Kampung Bangunrejo merupakan kampung-kota yang banyak menjadi tujuan para pendatang untuk tinggal mencari peruntungan nasib di Kota. Dekatnya dengan akses-akses publik dengan Kota Yogyakarta menjadikan Kampung Bangunrejo menjadi istimewa untuk ditinggali para urban migran. Kelurahan Kricak sendiri terdiri dari 3 kampung, antara lain kampung Bangunrejo di sisi selatan, Kampung Kricak Kidul di tengah, serta Kampung Jatimulyo di sisi utara, dengan keseluruhan tigabelas RW dan enampuluh satu RT. Pak Sarko juga menuturkan dahulu waktu awal beliau menempati Bangunrejo, rumah masih sangat sedikit hanya ada empatbelas rumah. Sekarang sudah ada ratusan kepala keluarga yang terdaftar dalam wilayah Kampung Bangunrejo Kelurahan Kricak.

Peran Pemerintah dalam Kampung Bangunrejo yang penulis temukan dari wawancara dan observasi adalah pembangunan beberapa fasilitas seperti taman, jembatan, talut secara fisik. Untuk peran non fisiknya lebih kepada sosialisasi bencana di sekolah seperti SDN Bangunrejo I dan II, serta program 3M..

Kampung Pingit merupakan salah satu kampung-kota yang paling dinamis dan representatif dengan tema penulis, yang berada di segmen Tombro Sungai Winongo. Kampung Pingit terletak di Kelurahan Bumijo, Kecamatan Jetis. Kelurahan Bumijo sendiri terletak tidak jauh dari Tugu Kota Yogyakarta. Kelurahan Bumijo dekat dengan layanan-layanan publik kota. Menurut data laporan TKPK Kota Yogyakarta tahun 2016, secara administratif wilayah Kelurahan Bumijo memiliki luas wilayah $0,58 \mathrm{~km}^{2}$ selain itu memiliki tigabelas RW dan limapuluh enam RT. Wilayah Utara Kelurahan Bumijo berbatasan dengan kelurahan Kricak, Kelurahan Cokrodiningratan dan Kelurahan Gowongan. Wilayah Selatan Kelurahan Bumijo berbatasan dengan Kelurahan Sosromenduran dan Kelurahan Pringgokusuman. Wilayah Timur Kelurahan Bumijo berbatasan dengan Kelurahan Cokrodiningratan, Kelurahan Sosromenduran dan Kelurahan Gowongan. Wilayah Barat Kelurahan Bumijo berbatasan dengan Kelurahan Tegalrejo dan Kelurahan Bener.

Di kampung Pingit sebenarnya terdapat program dari Kementerian Pekerjaan Umum mengenai Kotaku (kota tanpa kumuh) di mana Kotaku ini memperbaiki saluran air bersih, perbaikan drainase serta jalanan yang di paving. Semenjak ada program Kotaku ini mulai banyak fasilitas-fasilitas yang diperbaiki termasuk mengenai penerangan jalan. Fasilitas-fasilitas kesehatan juga cukup mudah dijangkau warga yaitu puskesmas yang letaknya tidak jauh dari rumah warga. Untuk fasilitas umum, akses pendidikan sendiri juga banyak SD, SMP dan SMA yang dekat dengan kampung, mengingat kampung mereka yang letaknya berada di tengah kota. Warga lama kian lama mulai merasakan berbagai perubahan lain yang terjadi pada kampung Pingit dan sungai Winongo. Di kampung Pingit ini juga terdapat rumah singgah milik Yayasan Sugiyo Pranoto. Rumah singgah Yayasan ini berada di bagian paling ujung 
kampung Pingit. Bentuk dari rumah singgah ini seperti kelas-kelas, di mana setiap terdapat sekitar 4-5 ruangan. Yayasan ini menampung gelandangan dan pengemis yang ada di Jogjakarta yang kemudian mereka diberi pelatihan-pelatihan agar mereka memiliki ketrampilan untuk mencari nafkah yang lebih baik. Selain itu seringkali kampung mereka kedatangan volunter mahasiswa yang mengajar ke kampung mereka. Biasanya para mahasiswa ini mengajar di malam hari, membantu anak-anak di sini mengerjakan PR mereka. Ketika bertanya kepada volunteer dari mana, para warga hanya tau bahwa mahasiswa ini bagian dari Yayasan Sugiyo Pranoto. Untuk kegiatan-kegiatan anak muda kampung seperti Karang Taruna sudah tidak lagi aktif di kampung mereka. Kegiatan-kegiatan lansia cukup aktif misalkan senam dan juga cek kesehatan. Acara-acara untuk ibu-ibu juga rutin dilakukan. Biasanya ibu-ibu ini melakukan arisan setiap 1 bulan sekali, baik itu arisan RT maupun RW. Warga masyarakat sebenarnya menaruh harapan besar terhadap kondisi lingkungan kampung mereka.

Untuk tetap menjalin relasi yang baik antar warga Kampung Pingit,Bapak Ketua RT setempat menuturkan banyak agenda perkumpulan rutin warga. Perkumpulan warga Kmpung Pingit yang sering berkegiatan adalah pkk ibu-ibu setiap minggu ketiga, arisan bapak-bapak yang warga kampung namakan semut ireng yang biasanya mengadakan simpan pinjam dana, untuk karang taruna sudah tidak begitu aktif, paud kampung, perkumpulan lansia setiap satu bulan sekali yang kegiatannya adalah berupa pemeriksaan.

Kampung Mancasan merupakan salah satu kampung-kota yang paling dinamis dan representatif dengan tema penulis, yang berada di segmen Wiranata Sungai Winongo. Kampung mancasan rw 09 merupakan salah satu kampung yang berada di bantaran sungai Winongo dengan wilayah tengah perkotaan. Kampung Mancasan terletak di kelurahan Wirobrajan dan kecamatan Wirobrajan. Khusus di bantaran sungai winongo, ada tiga RT yakni 40,41 dan 42. Kawasan rt 40 kampung Mancasan merupakan kawasan yang memiliki jumlah kepala keluarga yang lebih banyak dibanding kawasan yang lain. Dengan total jumlah penduduk di rt 40 adalah sebesar 289 jiwa. Kawasan RT 40 merupakan kawasan bantaran paling utara. Kemudian kawasan tengah atau sebelah selatan rt 40 adalah RT 41. Kawasan RT 41 memiliki jumlah penduduk sebesar 185 jiwa dengan jumlah KK 61. Komposisi jenis kelamin di kawasan rt 41 ini cukup seimbang dibandingkan dengan it 40 yang terbaca lebih banyak wanita selisih 21 dengan jumlah laki-laki. Untuk kawasan yang paling selatan di bantaran sungai winongo adalah wilayah RT 42 dengan jumlah penduduk 116 jiwa.

Dominan penduduk bantaran sungai kampung mancasan berprofesi di bidang nonformal seperti buruh harian lepas, karyawan swasta, wiraswasta, apoteker, tukang kayu, tukang jahit, pedagang, sopir dan mekanik. Perbandingan yang cukup mencolok antara pekerja bidang formal dan informal. Secara infrastruktur sudah jauh lebih baik sekarang kondisi pinggir sungai winonogo di kampung Mancasan, pinggir sungai sudah ditalud dan diberi jalan paving luasnya sekitar 1 meter dan diberi pagar pembatas. Terlihat pada gambar dibawah ini, pinggir sungai di kampung Mancasan sudah ditalud dan dipagar dan berbeda dengan kampung tejokusuman yang berseberangan dengan kampung Mancasan. Ungkapan pak rustamaji yang bercerita kepada penulis mengenai talud yang dibangun di kampung Mancasan bahwa dahulu ada pembangunan jembatan yang mau tidak mau itu berguna untuk melindungi tanah yang ada dipinggir sungai oleh masyarakat menginginkan untuk ditalud dan waktu itu dari dinas PU Kota Yogyakarta. Akhirnya dibuatkan di talud sepanjang batas RT 42 sampai RT 41 talud itu merupakan yang pertama dibangun terutama wilayah RT 42 . setelah itu program Pemerintah Kota Yogyakarta ada talud itu semuanya sampaiwilayah RT 40, kalau RT 40 belum lama sekitar 10 tahun yang lalu dimana secara keseluruhan dibangun talud. Program talud secara keseluruhan wilayah bantaran di kampung Mancasan sekitar tahun 2008. 


\section{Bantaran Sungai Winongo, RTLH dan kemiskinan}

Di bantaran Sungai Winongo memiliki konsentrasi penduduk yang tinggi karena bantaran menjadi tempat yang banyak dituju bagi para pendatang atau warga lokal yang tidak mendapatkan kesempatan tempat hidup yang lebih layak. Seringkali perkembangan kota menjadi tidak terkendali dan membuat permasalahan pemanfaatan lahan-lahan tidak layak menjadi pemukiman yang dihadapkan dengan banyak konsekuensi atas resiko dan bahaya. Permukiman adalah bagian dari lingkungan hunian yang terdiri atas lebih dari satu satuan perumahan yang mempunyai prasarana, sarana, utilitas umum, serta mempunyai penunjang kegiatan fungsi lain di kawasan perkotaan atau kawasan perdesaan (SLDH, 2014: 23).

Menurut Dinas Lingkungan Hidup Kota Yogyakarta tahun 2017 Mengatakan bahwa pengendalian pemanfaatan ruang yang kurang optimal diindikasikan dari rendah (kurang) atau tidak adanya fungsi lindung kawasan sempadan sungai, kecenderungan perubahan peruntukan ruang publik menjadi ruang privat dan rendah (kurang) atau tidak adanya fungsi lindung kawasan sepadan sungai. Berbicara tentang Rumah Tidak layak Huni tidak terlepas dari kemiskinan, lebih pada tataran yang operasional, kemiskinan juga terkait dengan ketidakmampuan mencapai faktor-faktor diluar pendapatan (non income factors) seperti akses pada layanan publik dan ifrastruktrur dasar yang mencakup kesehatan, pendidikan, perumahan, sanitasi dan air bersih. Pendataan RTLH menggunakan kualitas tempat tinggal sebagai faktor penciri utama rumah tangga sasaran, sehingga dengan ciri tertntu rumah tangga dapat dikategorikan sebagai rumah tangga sasaran atau tidak.

Menurut BPS D.I Yogyakarta No. 37/07/34/Th.XV, 1 Juli 2013, secara umum kemiskinan didefinisikan sebagai suatu kondisi kehidupan dimana terdapat sejumlah penduduk tidak mampu mendapatkan sumber daya yang cukup untuk memenuhi kebutuhan pokok (basic needs) minimum dan mereka hidup di bawah tingkat kebutuhan minimum tersebut. Berdasarkan data lapangan yang diperoleh BPS Kota Yogyakarta untuk masalah kemiskinan di perkotaan jumlah penduduk miskin tahun 2008 sebesar 81.334 jiwa atau sebesar 9,44\%. Pada tahun 2009 Dinas Sosial Tenaga Kerja dan Transmigrasi Kota Yogyakarta melakukan pencatatan angka penduduk miskin Kota Yogyakarta sebesar 68.998 jiwa, jika dilihat pada jumlah tersebut terbagi menjadi 32.997 jiwa tergolong hampir miskin, 34.152 jiwa tergolong miskin dan 1.849 jiwa tergolong fakir miskin. Pada tahun 2010 jumlah penduduk miskin turun menjadi 65.371 jiwa dan tahun 2011 angka kemiskinan kembali turun sebesar 54.530. Pada tahun 2012 angka kemiskinan naik menjadi sebesar 68.188 Jiwa. Sedangkan tahun 2013 angka kemiskinan turun kembali menjadi 64.699 jiwa. Pada tahun 2014 jumlah penduduk miskin kembali turun menjadi 60.230 jiwa. Sedangkan pada tahun 2015 jumlah penduduk miskin kembali turun menjadi 60.195 jiwa.

\section{Praktik Informalitas Warga Bantaran Sungai Winongo}

Fenomena urbanisasi di bantaran sungai Winongo sangat kental kita jumpai di kampung Bangunrejo, Kampung Bener, Kampung Mancasan dan kampung-kampung bantaran winongo lainnya. Wilayah-wilayah tersebut merupakan kampung kota bantaran sungai winongo yang letaknya di tengah perkotaan Yogyakarta. Menurut data yang diunggah oleh Bappenas Kota Yogyakarta, dahulu Kota Yogyakarta pada tahun 1985 penduduk yang tinggal di daerah perkotaan meliputi $26,1 \%$ dan pada tahun 1988 diperkirakan meningkat menjadi $27,6 \%$. Kasus mengenai urbanisasi sendiri jangan hanya dipandang sebagai kasus kependudukan saja melainkan harus dipandang sebagai fenomena sosial, budaya dan ekonomi. Di Kampung Bangunrejo penulis menjumpai beberapa informan yang merupakan warga pendatang. Para warga pendatang di Kampung Kota bantaran Sungai Winongo, kebanyakan yang berasal dari daerah sekitar Kota Yogyakarta seperti Gunungkidul, Bantul, dan luar Jawa yakni 
Lampung. Kedatangan mereka ke kota Yogyakarta adalah mencari peruntungan nasib yang lebih baik ketimbang di daerah asal. Mereka datang dengan latar belakang pendidikan dan ketrampilan yang berbeda-beda. Meskipun tidak memiliki pendidikan, pendatang yang memiliki ketrampilan akan mampu bekerja di sudut-sudut Kota Yogyakarta menjadi tenaga kerja sehingga berhasil menjemput impian atas perbaikan hidup dari daerah asal begitupun sebaliknya jika pendatang sama sekali tidak memiliki pendidikan dan keterampilan maka akan hanya menjadi perpindahan kondisi kemiskinan.

Menuju kampung atau pemukiman bantaran Sungai Winongo dapat diakses melalui jalan yang pada mulanya lebar (karena dapat dilalui oleh dua sepeda motor berlawanan arah), hingga kemudian semakin menyempit ketika menuju ke tengahtengah kampung. Jalan kampung-kota di bantaran Sungai Winongo ini berbentuk gang-gang kecil. Di hari libur seperti hari Minggu misalnya, penggunaan jalan kampung menjadi bertambah karena hampir seharian mereka berada di rumah selama libur. Di Minggu pagi, sambil berbincang dengan tetangga sekitar, para ibu-ibu dan remaja perempuan biasanya mencuci baju atau memasak.

Rutinitas pekerjaan yang dilakukan dari hari Senin hingga Sabtu, oleh warga di kampung-kampung-kota bantaran Sungai Winongo untuk menyambung hidup dengan perolehan upah mingguan hingga bulanan. Sedangkan, untuk ibu-ibu kampung yang memilih untuk berada di rumah sebagai ibu rumah tangga biasanya di pagi hari mereka telah disibukkan dengan beragam pekerjaan domestik seperti mencuci, memasak, membersihkan rumah, dan lain sebagainya. Karena beragam aktivitas tersebut telah dimulai di pagi buta, praktis, tak sampai siang hari mereka telah duduk santai di depan rumah sambil ngobrol atau sekedar menonton televisi bersama tetangga. Kemudian, anak-anak seusia remaja yang tidak lagi meneruskan pendidikannya, kebanyakan dari mereka telah bekerja sebagai karyawan-karyawati toko, biasanya berangkat agak siang bergantung pada shift kerja. Di pagi hari, para remaja ini disibukkan dengan gadgetnya. Menjelang siang, anak-anak mulai pulang dari sekolah.

Bercerita sebentar kepada orang-orang di rumah mengenai kejadian selama di sekolah, selepas itu biasanya mereka bermain dan jajan demi menghabiskan sisa uang sakunya bersama teman-temannya. Pola pemukiman yang saling berimpit, antara ruang privasi dan ruang publik menjadi tidak ada pembeda. Pertumbuhan penduduk di Kota Yogyakarta berdampak kepada aktivitas pemenuhan kebutuhan pokok maupun sekunder yang juga meningkat.

Aktifitas dalam rangka memenuhi kebutuhan tersebut akan juga meningkat baik dalam dimensi-dimensi ekonomi, sosial dan lingkungan. Sebagian besar masyarakat yang menempati kawasan ini memiliki tingkat ekonomi menengah ke bawah. Penduduk memanfaatkan bantaran sungai sebagai tempat hunian dan beraktivitas. Akibatnya terjadi eksploitasi alam yang berlebihan, perubahan tata guna lahan yang tak terkendali dan menurunnya daya dukung lingkungan dari aktifitas tersebut. Selain aktifitas ekonomi warga, pendidikan merupakan hal yang sangat krusial karena dengan pendidikan yang baik, setiap orang memiliki bekal pengetahuan dan keterampilan, mempunyai pilihan untuk mendapat pekerjaan, dan menjadi lebih produktif sehingga dapat meningkatkan pendapatan. Dengan demikian pendidikan dapat memutus mata rantai kemiskinan dan menghilangkan eksklusi sosial, untuk kemudian meningkatkan.

Penduduk disekitar sungai Winongo umumnya adalah masyarakat yang berasal dari dalam Yogyakarta maupun dari luar Yogyakarta yang memanfaatkan bantaran sungai sebagai tempat hunian dan beraktivitas. Berdasarkan data kependudukan badan pusat statistik kota Yogyakarta, penduduk bantaran Sungai Winongo yang memiliki tingkat kepadatan paling tinggi berada di Kecamatan Ngampilan, dengan jumlah penduduk 16.932 jiwa dan kepadatan penduduk 20.649 jiwa/km2. Kecamatan Wirobrajan mempunyai jumlah penduduk 25.831 jiwa dengan kepadatam 14.677 jiwa/ $\mathrm{km}^{2}$, Kecamatan Gedongtengen mempunyai jumlah penduduk 18.216 jiwa dengan 
kepadatan penduduk $18.975 \mathrm{jiwa} / \mathrm{km}^{2}$, Kecamatan Jetis mempunyai jumlah penduduk 23.911 jiwa dengan kepadatan pendudukn14.065 jiwa/ km², sedangkan Kecamatan Tegalrejo mempunyai 37.757 jiwa dan kepadatan mencapai 12.975 jiwa/ km². Untuk status lahan yang warga tempati di beberapa Kampung Kota seperti Kampung Bener bagian selatan, Kampung Tejokusuman, Kampung Notoyudan, Kampung Pingit, Kampung Jatimulyo merupakan lahan atau tanah Wedi Kengser \& Sultan Ground. Terdapat tulisan yang terpampang di pinggir sungai Winongo Kampung Bener bahwa tanah diatas merupakan Wedi Kengser yang dilarang membuat bangunan. Namun beberapa tanah juga sudah memiliki surat hak milik pribadi.

Keberadaan fasilitas umum seperti sanitasi, MCK, IPAL merupakan salah satu fasilitas bagi masyarakat agar dapat tetap sehat dan terhindar dari berbagai macam penyakit. Kurangnya kesadaran pemanfaatan fasilitas ini atau bahkan menggunakan sungai sebagai sarana sanitasi dan MCK dapat merugikan masyarakat itu sendiri. Beberapa sarana yang ditemukan di sekitar wilayah sungai Winongo adalah saluran sanitasi dan drainase. Selain itu, terdapat beberapa taman untuk ruang terbuka hijau di beberapa segmen sungai Winongo seperti di RTH Bener Kelurahan Bener, RTH Greskap di Kelurahan Pringgokusuman, RTH Ngampilan di kelurahan Ngampilan. Pada salah satu titik di kawasan sungai Winongo terdapat sarana pengolahan sanitasi, biopori, resapan air, IPAL, biogas yang dimanfaatkan untuk warga yakni di Kampung Bener. Namun kondisi tersebut belum merata terpenuhi di setiap wilayah, ini juga yang kemudian menjadi fokus permasalahan utama bagi seluruh pihak baik warga, FKWA dan Pemerintah Kota Yogyakarta.

\section{SIMPULAN}

Kondisi sosial dan budaya masyarakat di kawasan bantaran Sungai Winongo secara umum tidak terlepas dari budaya kampung para penghuninya, dimana nilai-nilai budaya feodal Jawa berkembang dan berinteraksi dengan budaya kawasan perkotaan, sehingga membentuk suatu keunikan tersendiri. Semangat membangun kampung sendiri, masih adanya pemanfaatan lahan dengan sumber ekonomi tradisional, terjadinya kepadatan penduduk di sekitar pusat ekonomi Kota Yogyakarta adalah contoh hasil interaksi dua kondisi tersebut. Nilai-nilai sosial dan budaya yang ada di masyarakat kampung kota di bantaran secara langsung maupun tidak langsung saling mempengaruhi interaksi warga dengan Sungai Winongo. Hal positif yang bisa ditemukan ialah semangat kebersamaan, kemauan untuk maju berkembang, serta budaya gotong royong (budaya kampung-kota). Pengaruh negatif yang ditemukan ialah ditemukan masyarakat yang memanfaatkan ruang dan fasilitas kota menjadi hunian dan sumber ekonomi mereka karena keterbatasan atas akses pendidikan, ekonomi maupun kesehatan

Praktik Keseharian warga kelima kampung-kota bantaran Sungai Winongo dalam penelitian ini yakni Kampung Bener, Kampung Bangunrejo, Kampung Pingit, Kampung Serangan dan Kampung Mancasan telah menggambarkan aktivitas yang berlangsung dalam menanggapi kebutuhan sehari-hari penduduk kota sebagai strategi adaptasi untuk tetap bertahan dan meneruskan keturunan. Dengan praktik-praktik yang sudah menjadi strategi oleh warga selama jangka waktu yang panjang itu menjadikan warga bantaran Sungai Winongo mengembangkan sumberdaya yang ada seperti membuka jaringan sosial yang lebih luas dan berhasil membantu menggantikan kekurangan sumber yang lain.

\section{DAFTAR PUSTAKA}

Alan Gilbert \& Josef Gugler. (1996). "Urbanisasi dan kemiskinan di dunia ketiga" pengantar: DR. Nasukin. Yogyakarta: PT. Tiara Wacan Yogya. 
Alvares, Eko. (2002). Morfologi Kota Padang, Disertasi Doktor Program Studi IImu Teknik pada Program Pascasarjana Universitas Gajah Mada. Yogyakarta

Asrinaldi, DR. (2012). Politik Masyarakat Miskin Kota. Yogyakarta: Gava Media

Berita Resmi Statistik D.I. Yogyakarta No. 37/07/34/Th.XV, 1 Juli 2013

Berita Resmi Statistik D.I. Yogyakarta No. 43/08/34/Th.XVIII, 17 Juli 2017

Bintarto, R. (1986). Urbanisasi dan Permasalahannya. Jakarta : Ghalia Indonesia.

Bintarto, R. (1989). Interaksi Desa-Kota dan Permasalahanya. Jakarta: Ghalia Indonesia

BPS D.I Yogyakarta No. 37/07/34/Th.XV 1 Juli 2013

Budihardjo, Eko. (1977). Jatidiri Arsitektur Indonesia. Alumni: Bandung.

Budiharjo, Eko. (1992). Sejumlah Masalah Perkampungan Kota. Bandung: Alumni Chambers, R. (1985). Rural Development : Putting The Last First. London ; New York. Coleman, J. (1990). "Dasar Teori Sosial”. Cambridge Mass: Harvard University Press Darmosugito. (1956). "Sedjarah Kota Yogyakarta" dalam Kota Yogyakarta 200 Tahun. Oktober 1756 - 7 Oktober 1956. Jogjakarta 